\title{
Manger du riz ou ne pas manger du riz ? Le choix moken (archipel des Mergui)
}

Jacques Ivanoff

\section{(2) OpenEdition}

\section{Journals}

Édition électronique

URL : https://journals.openedition.org/tc/414

DOI : $10.4000 /$ tc. 414

ISSN : 1952-420X

Éditeur

Éditions de l'EHESS

\section{Édition imprimée}

Date de publication : 1 avril 1999

ISSN : 0248-6016

\section{Référence électronique}

Jacques Ivanoff, « Manger du riz ou ne pas manger du riz ? Le choix moken (archipel des Mergui) », Techniques \& Culture [En ligne], 31-32 | 1999, mis en ligne le 26 octobre 2005, consulté le 29 septembre 2022. URL : http://journals.openedition.org/tc/414 ; DOI : https://doi.org/10.4000/tc.414

Ce document a été généré automatiquement le 29 septembre 2022.

Tous droits réservés 
Manger du riz ou ne pas manger $d u$ riz ? Le choix moken (archipel des Mergui)

Jacques Ivanoff 